\title{
Unique spectral features of DNA infrared bands of some microorganisms
}

\author{
M. Khalique Ahmed*, Frank Amiama and Earl A. Sealy \\ Department of Science, College of Arts and Sciences, Lynn University, Boca Raton, FL, USA
}

\begin{abstract}
Half dozen microorganisms (Serratia marcescens, Klebsiella pneumonia, Staphylococcus aureus, Bacillus subtilis, Mycobacterium smegmatis and Saccharomyces cerevisiae) were cultivated, and their infrared spectra were recorded in the attenuated total reflection mode. Both the intensities and frequencies of the B-DNA and Z-DNA bands in the spectral region of $1250-900 \mathrm{~cm}^{-1}$ were found to be different for different microorganisms. We suggest that characterization and identification of microorganisms may be possible through analysis of their DNA bands only without the analysis of the full range (4000$700 \mathrm{~cm}^{-1}$ ) of their infrared spectra.
\end{abstract}

Keywords: Microorganisms, attenuated total reflection, FT-IR, DNA, characterization, identification

\section{Introduction}

The identification of microorganisms is important in the monitoring of the infectious diseases and in the understanding of the changes in the resistance patterns of the known microorganisms [9]. The traditional methods of microorganism identification involve a variety of chemical tests $[2,3,11,16]$ which are laborious and time intensive. In efforts to develop simple and efficient physiochemical instrumental methods for the identification of the microorganisms, several optical and chromatographic techniques have been reported [9]. Infrared and Raman spectral techniques have been shown to be useful in the identification and characterization of microorganisms [13]. Generally both infrared and Raman techniques utilize chemomatrics techniques that use all bands due to the different functional groups present in the sample for the analysis. In this note we report some preliminary evidence that suggests that characterization and the identification of the microorganisms may be possible through the analysis of the infrared spectra of B-DNA and Z-DNA bands of microorganisms only without taking into consideration the bands due to all constituents of the microorganisms.

\section{Materials and methods}

\subsection{Microbial cultivation}

The six organisms used in this study are listed in Table 1 and were obtained as batch cultures from Carolina Biological Supplies Company, York Road, Burlington, NC 2715, USA.

\footnotetext{
${ }^{*}$ Corresponding author: M. Khalique Ahmed, Department of Science, College of Arts and Sciences, Lynn University, 3601 North Military Trail, Boca Raton, FL 33431, USA. Tel.: +1 561237 7024; Fax: +1 561237 7400; E-mail: kahmed@lynn.edu.
} 
Table 1

Microorganisms Studied

\begin{tabular}{ll}
\hline Microorganism & Growth medium \\
\hline $\begin{array}{l}\text { Prokaryotic } \\
\text { Serratia marcescens }\end{array}$ & Gram negative nutrient broth $\left(25^{\circ} \mathrm{C}\right)$ \\
Bacillus subtilis & Gram positive nutrient agar $\left(37^{\circ} \mathrm{C}\right)$ \\
Mycobacterium smegmatis & Acid fast nutrient broth $\left(37^{\circ} \mathrm{C}\right)$ \\
Staphylococcus aureus & Gram positive BHI agar $\left(37^{\circ} \mathrm{C}\right)$ \\
Klebsiella pneumonia & Gram Negative nutrient agar $\left(37^{\circ} \mathrm{C}\right)$ \\
Eukaryotic & \\
Saccharomyces cerevisiae & Unicellular sabaroud dextrose agar $\left(30^{\circ} \mathrm{C}\right)$ \\
\hline
\end{tabular}

Serratia marcescens and Mycobacterium smegmatis were grown in Nutrient Broth and incubated at $25^{\circ} \mathrm{C}$ and $37^{\circ} \mathrm{C}$, respectively. The Nutrient Broth was prepared by dissolving $5.0 \mathrm{~g}$ of $\mathrm{NaCl}, 10.0 \mathrm{~g}$ of Neopeptone (Difco Laboratories \#525677), $25.0 \mathrm{ml}$ of Beef Broth (Swanson Beef Broth \#2421-503-5X) in $975.0 \mathrm{ml}$ of distilled water and adjusted to $\mathrm{pH}$ 7.0. The broths were sterilized by autoclaving for 15 min at 121 psi. The broth tubes were inoculated with the microorganism and incubated at the required temperature for $48 \mathrm{~h}$.

Staphylococcus aureus was grown on Brain Heart Infusion Agar at $37^{\circ} \mathrm{C}$. The Brain Heart Infusion Agar was prepared by dissolving $23.0 \mathrm{~g}$ of Nutrient Agar, dehydrated media (Carolina Biological Supplies \# Cat. No. 78-5301) and $100.0 \mathrm{ml}$ of Brain Heart Infusion Broth (Carolina Biological Supplies \# Part 82-4582) in $900.0 \mathrm{ml}$ of distilled water and adjusted to $\mathrm{pH}$ 7.0. The Brain Heart Infusion Agar was autoclaved for $15 \mathrm{~min}$ at $121 \mathrm{psi}$.

Klebsiella pneumonia and Bacillus subtilis were both grown on Nutrient Agar at $37^{\circ} \mathrm{C}$. The Nutrient Agar was prepared by dissolving $23.0 \mathrm{~g}$ of Nutrient Agar, dehydrated media (Carolina Biological Supplies \# Cat. No. 78-5301) in $1000 \mathrm{ml}$ of distilled water, adjusted to $\mathrm{pH} 7.0$ and autoclaved for $15 \mathrm{~min}$ at psi 121.

Saccharomyces cerevisiae was grown on Sabourad Dextrose Agar at $30^{\circ} \mathrm{C}$. Thirty grams of Sabourad Dextrose Agar (Difco Laboratories, Detroit, MI, USA, \# Control No. 635475) was dissolved in $1000 \mathrm{ml}$ of distilled water, adjusted to $\mathrm{pH} 5.6$ and autoclaved for $15 \mathrm{~min}$ at $121 \mathrm{psi}$.

Staphylococcus aureus, Saccharomyces cerevisiae, Klebsiella pneumonia and Bacillus subtilis cultures were streaked on to the relevant agar plates and incubated for $48 \mathrm{~h}$ at their appropriate temperatures.

\subsection{Sample preparation and spectral measurements}

\subsubsection{Organisms grown on agar medium}

Small amounts of the microorganisms (Saccharomyces cerevisiae, Staphylococcus aureus, Klebsiella pneumonia and Bacillus subtilis) were removed from the agar plate, after $48 \mathrm{~h}$, with a calibrated $(0.5 \mathrm{~cm}$ in diameter) platinum loop and suspended in $100 \mu \mathrm{l}$ of distilled water, and agitated for 1-2 min (Fisher Scientific Touch Mixer, Model 232, Speed 10). Subsequently, $20 \mu \mathrm{l}$ ( $\sim 1$ drop) of the suspensions were placed on the ZnSe crystal of the MIRacle ${ }^{\circledR}$ ATR accessory (PIKE technologies, Madison, WI, USA) fitted in the Bruker Vector 33 FT-IR Spectrophotometer. The sample was allowed to dry on the ZnSe crystal and the single beam spectrum of the dry film was recorded and then ratioed against the single beam spectrum of the bare $\mathrm{ZnSe}$ crystal to obtain the absorbance spectra. The spectrometer was equipped with a $\mathrm{KBr}$ beam splitter and deuterated triglycine sulfate (DTGS) room temperature detector. Spectra 
were recorded with a resolution of $4 \mathrm{~cm}^{-1}$ and 64 scans were averaged for each spectrum. The spectrometer's optics was sealed from the atmosphere but its compartment was not purged during measurements. The spectra were run and processed with Bruker OPUS software.

\subsubsection{Organisms grown in broth medium}

$20 \mu \mathrm{l}$ ( $\sim 1$ drop) of the microbial broth suspension (Serratia marcescens and Mycobacterium smegmatis) was removed from the culture tube and the absorbance spectra of their thin films were recorded with the same procedure as used for the agar medium microorganisms.

\section{Results and discussion}

Infrared spectra in the range of $3750-950 \mathrm{~cm}^{-1}$ of the six microorganisms are shown in Figs 1 and 2. The major peaks in the spectra arise from the vibrations of the functional groups belonging to the DNA, RNA, proteins and lipids of the microorganisms. The assignments of the major peaks are indicated in Figs 1 and 2 and are based upon previous work on the biomaterials [18]. The peaks around 3200 and $2900 \mathrm{~cm}^{-1}$ are mainly due to the $\mathrm{NH}$ stretching vibrations of the proteins and $\mathrm{CH}$ stretching vibrations of the lipids. The peaks at around $1650 \mathrm{~cm}^{-1}$ (Amide I) and $1540 \mathrm{~cm}^{-1}$ (Amide II) are due to the $\mathrm{C}=\mathrm{O}$ stretching and NH bending modes of the peptide linkage of the proteins. The peaks around $1450 \mathrm{~cm}^{-1}$ are due to the $\mathrm{CH}$ bending modes. The rest of the peaks of Figs 1 and 2 are mainly due to the DNA and RNA vibrations and are discussed further in this section.

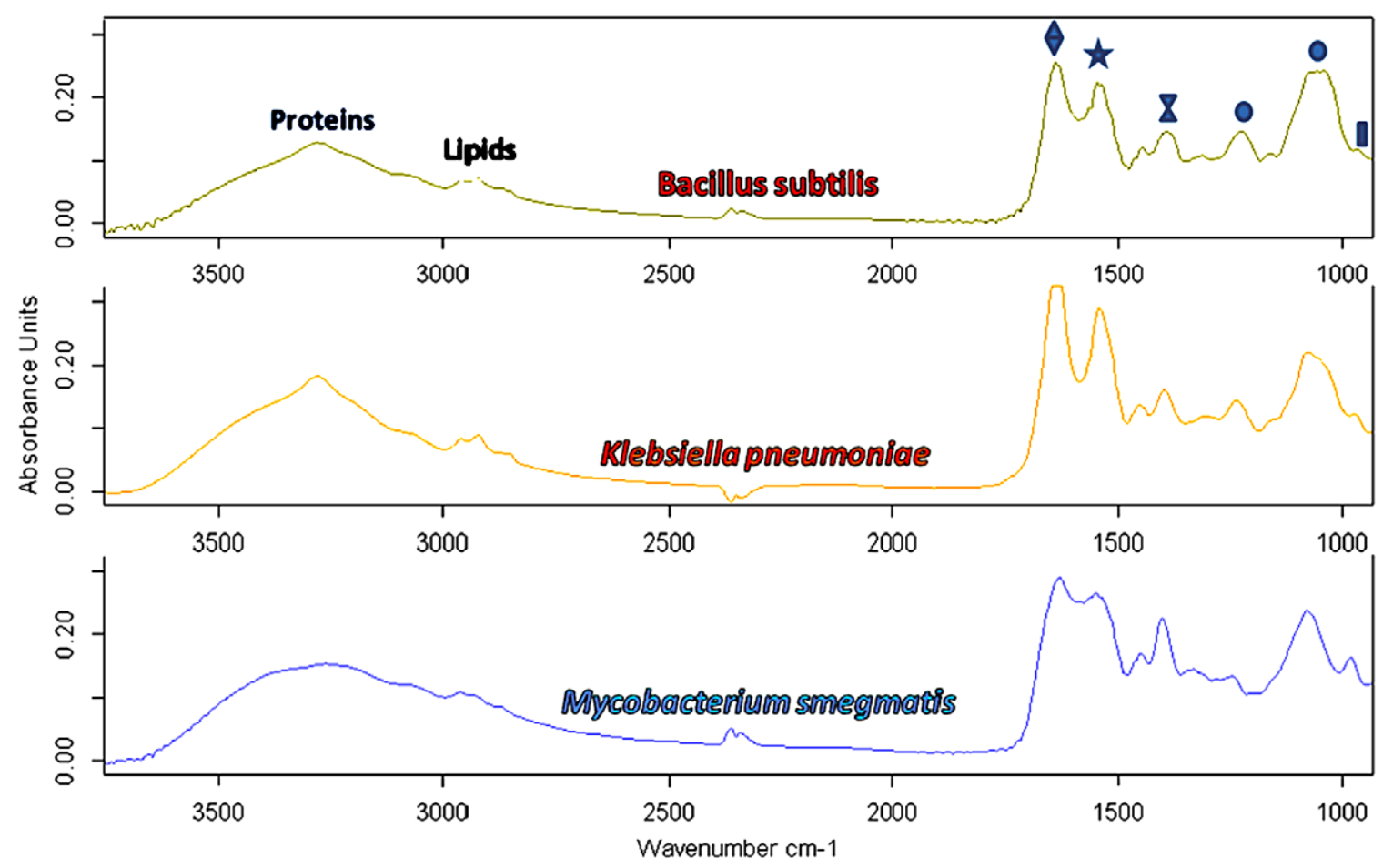

Fig. 1. Infrared spectra of Saccharomyces cerevisiae, Staphylococcus aureus and Serratia marcescens. The symbols for the protein, DNA and lipid bands are: Amide I $(\bullet)$, Amide II $(\star)$, B-DNA $(\bullet)$, Z-DNA $(\mathbf{\square})$ and lipids $(\mathbf{Z})$. 

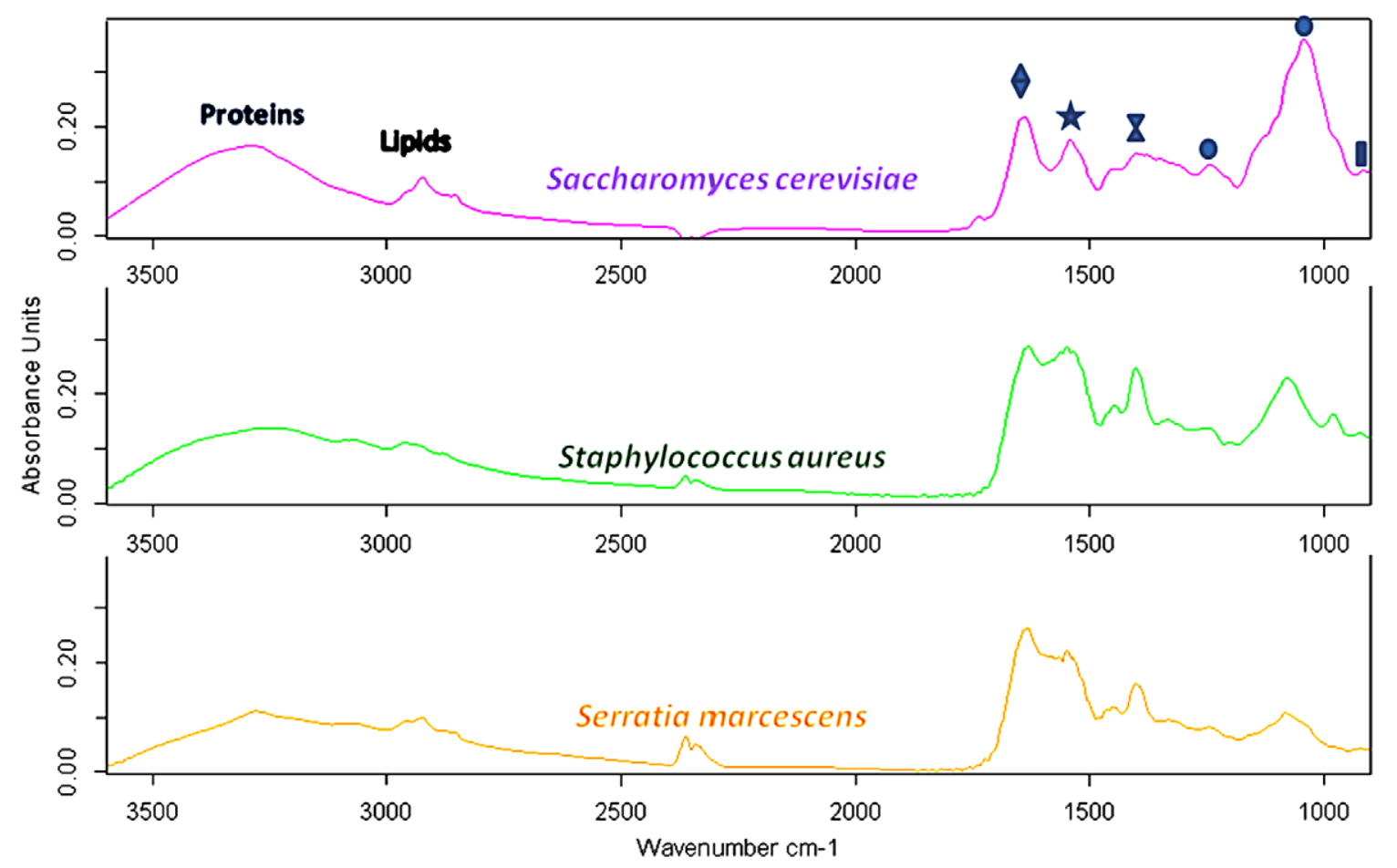

Fig. 2. Infrared spectra of Bacillus subtilis, Klebsiella pneumonia and Mycobacterium smegmatis. The symbols for the protein, DNA and lipid bands are: Amide I ( $)$, Amide II ( $\star$ ), B-DNA $(\bullet)$, Z-DNA ( $)$ and lipids $(\mathbf{Z})$.

The dynamical nature of the DNA has been studied by many workers [5,7,19]. The DNA exists in a rigid A form, flexible B form [5] and in a left-handed Z form [7,19]. Information about DNA geometry can be gleaned from the FTIR spectra $[1,6,10,19,20]$. The DNA absorption bands in the infrared spectra occur in the region of $1375-875 \mathrm{~cm}^{-1}$ range of the infrared spectra [19]. In the infrared spectra of the cellular biomaterials, the band around $965 \mathrm{~cm}^{-1}$ is thought to arise from $\mathrm{C}-\mathrm{C}$ and $\mathrm{C}-\mathrm{O}$ vibrations in deoxyribose and is assigned as a DNA maker band $[8,12,17]$ which may indicate both right and lefthanded helices [7]. The bands around 1220-1240 and 1080-1090 $\mathrm{cm}^{-1}$ arise from the antisymmetric and symmetric vibrations of the $\mathrm{PO}_{2}{ }^{-}$groups of the DNA $[6,8,10,12,14]$ and are thought to originate from the backbone of the B form of the DNA. The bands at $920-930$ and $860-865 \mathrm{~cm}^{-1}$ have been shown to reflect the phosphate-sugar backbone of Z [7] and A [7,20] forms of the DNA, respectively. The concise summary of the infrared bands of the DNA conformations is given in Table 2.

The infrared bands of the DNA conformations of the microorganisms are shown in Figs 3 and 4 and the bands due to B, Z and DNA maker bands are marked with arrows for clarity. The A-DNA bands are not shown in Figs 3 and 4 as their intensities were too weak for observation. As is clear from the Figs 3 and 4, the Z-DNA bands are very weak compared with the DNA marker and B-DNA bands. In fact, ZDNA are not even perceptible in some microorganisms. The B-DNA band envelops around $1080 \mathrm{~cm}^{-1}$ in Figs 3 and 4 have different shapes and intensities in different microorganisms. The varying intensity of the $1080 \mathrm{~cm}^{-1}$ band in different organisms indicates [4] that the DNA content of different organism is different.

The analysis of materials may be enhanced with the second derivative infrared spectroscopy [21]. Figure 5 shows the second derivative spectra of the studied microorganisms in the fingerprint region. The 
Table 2

Assignments of the infrared bands of the various conformations of the DNA

\begin{tabular}{ll}
\hline Band $\left(\mathrm{cm}^{-1}\right)$ & Assignment \\
\hline 965 & DNA marker \\
$1220-1240$ & B-DNA \\
$1080-1090$ & B-DNA \\
$920-930$ & Z-DNA \\
$860-865$ & A-DNA \\
\hline
\end{tabular}

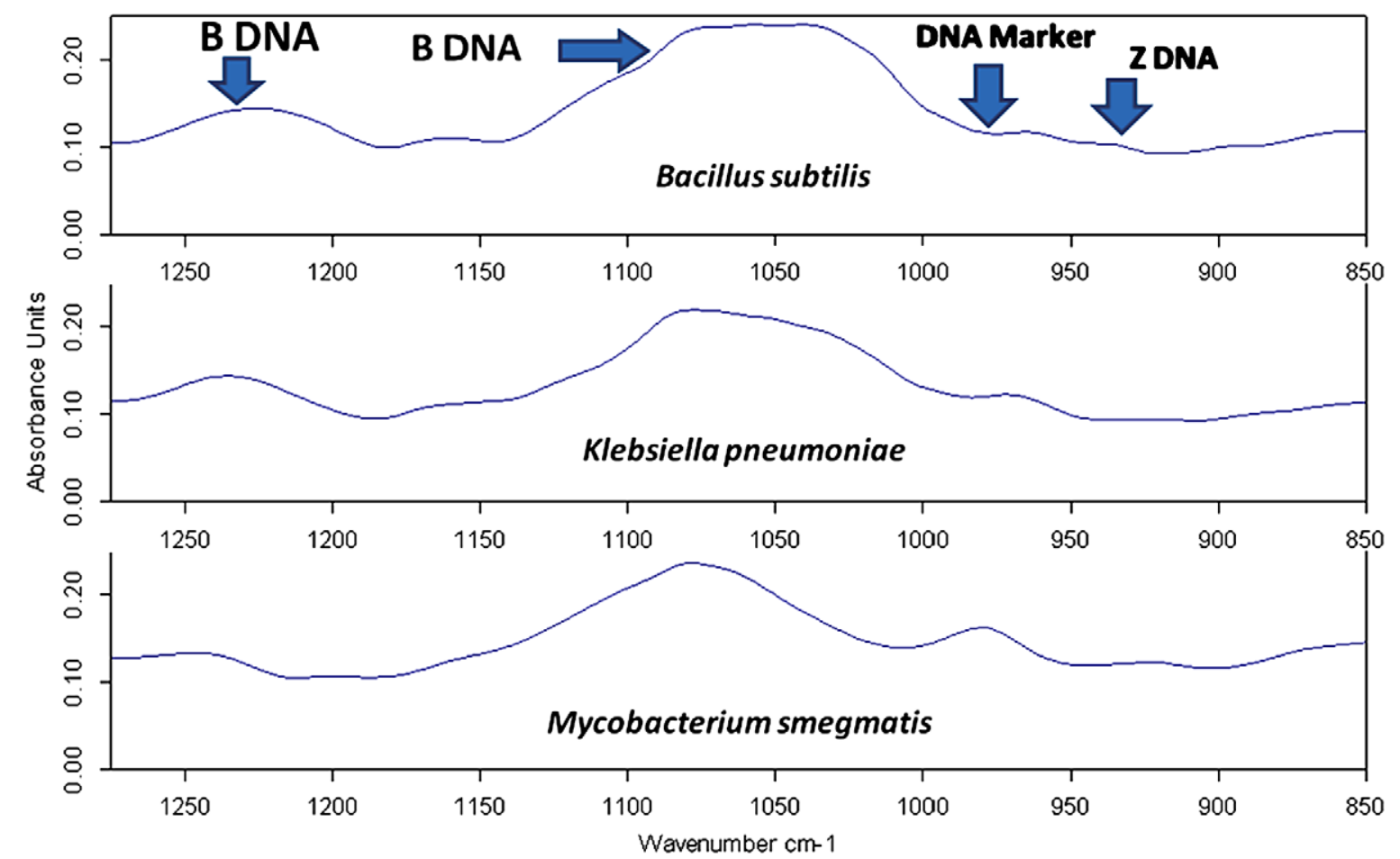

Fig. 3. Infrared spectra of Bacillus subtilis, Klebsiella pneumonia and Mycobacterium smegmatis in the region of $1275-850 \mathrm{~cm}^{-1}$. DNA bands have been labeled with arrows.

spectral differences between the microorganisms are more pronounced in the second derivative spectra than in the absorbance spectra. Although, it is difficult to associate each derivative spectrum to the individual microorganism due to the overlapping peaks, the point that can be made is that each derivative spectrum is unique for each microorganism. The future studies involving DNA peaks of infrared spectra of a large number of microorganisms will be helpful in generating a data base of infrared bands of the DNA content of the microorganisms which may later be used as an alternative method for the characterization and identification of microorganisms.

Several authors including Naumann and co-workers [15] have employed FT-IR spectroscopy for the characterization of microorganisms. The focus of Naumann et al. [15] was on the fingerprint spectra in the region of 1850-900 $\mathrm{cm}^{-1}$ whereas in our study we have focused on the infrared bands of the DNA conformations. Our approach is similar to Naumann et al. procedure; however, it provides insights into 


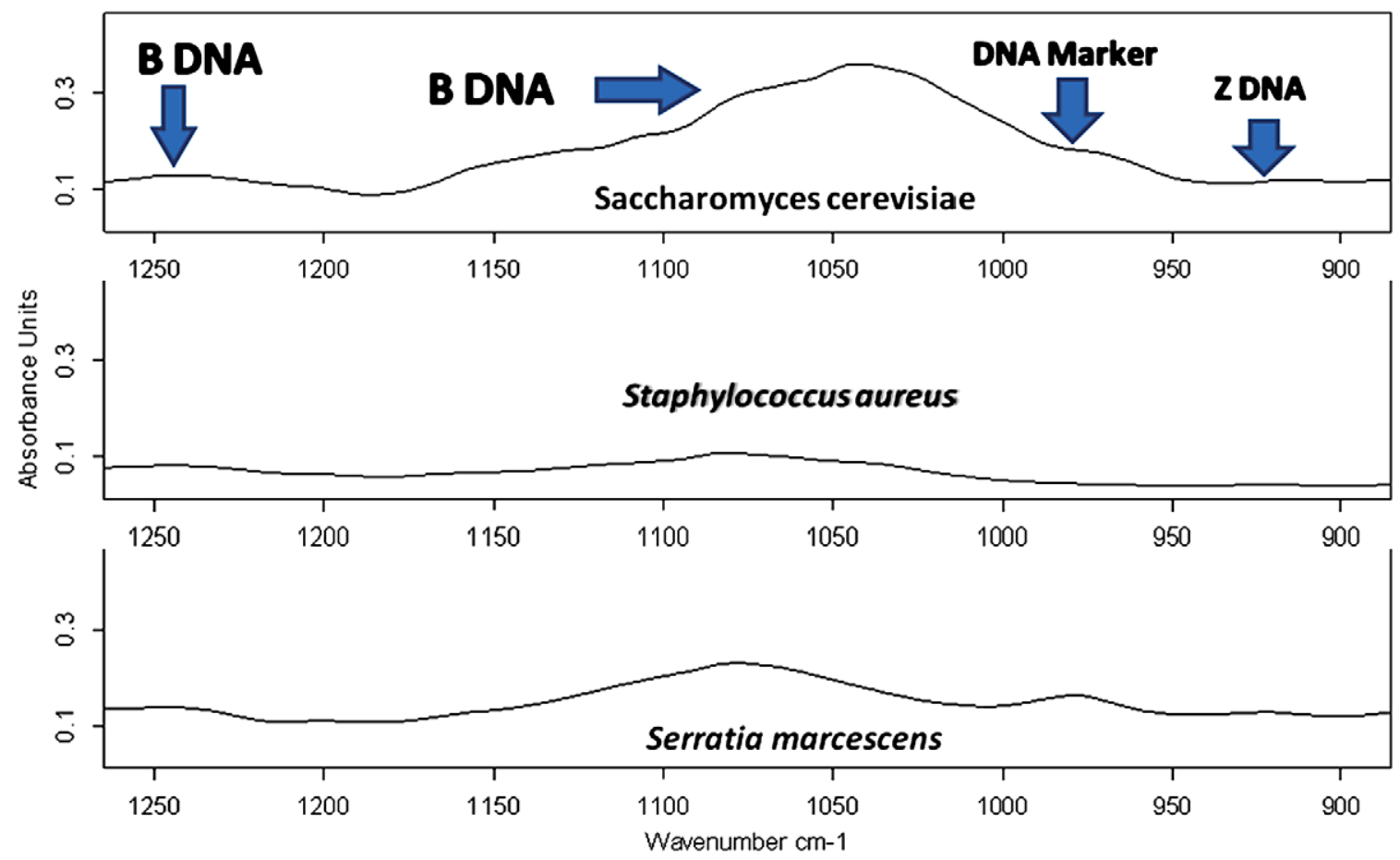

Fig. 4. Infrared spectra of Bacillus subtilis, Klebsiella pneumonia and Mycobacterium smegmatis in the region of $1265-885 \mathrm{~cm}^{-1}$. DNA bands have been labeled with arrows.

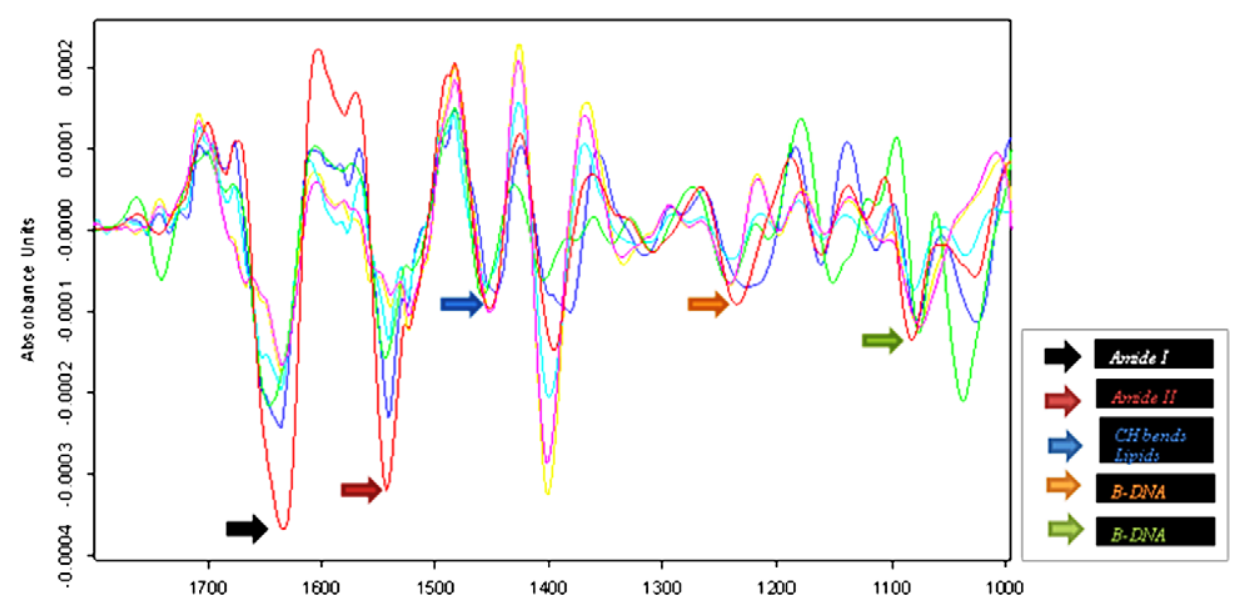

Fig. 5. Second derivative infrared spectra of the studied microorganisms.

the conformational differences of the DNA in different microorganisms.

In conclusion attenuated total reflection infrared spectra of the dry films of the microorganisms have unique DNA spectral features that may help us in the determination of their presence or absence in biomedical samples. 


\section{References}

[1] M. Banyay and A. Graslund, Structural effects of cytosine methylation on DNA sugar pucker studied by FTIR, Journal of Molecular Biology 324 (2002), 667-676.

[2] S. Bascomb, in: Methods in Microbiology, Vol. 19, R.R. Colwell and R. Grigorova, eds, Academic Press, London, 1987, pp. 105-160.

[3] T. Bergan (ed.), Methods in Microbiology, Vols 14-16, Academic Press, London, 1984.

[4] O. Bozkart, M.D. Bilgin and S. Severcan, Spectroscopy 21 (2007), 151.

[5] R.E. Dickerson and H.-L. Ng, DNA structure from A to B, Proceedings of the National Academy of Sciences of the United States of America 98 (2001), 6986-6988.

[6] M. Diem, S. Boydston-White and L. Chiriboga, Infrared spectroscopy of cells and tissues: shining light onto a novel subject, Applied Spectroscopy 53 (1999), 148-161.

[7] D. Dohy, M. Ghomi and E. Taillandier, Interpretation of DNA vibration modes: III - The behavior of the sugar pucker vibration modes as a function of its pseudorotation parameters, Journal of Biomolecular Structure and Dynamics 6 (1989), 741.

[8] G.I. Dovbeshko, V.I. Chegel, N.Y. Gridina, P. Repnyska, Y.M. Shirshov, V.P. Tryndiak, I.M. Todor and G.I. Solyanik, Surface enhanced IR absorption of nucleic acids from tumor cells: FTIR reflectance study, Biopolymers 67 (2002), 470486.

[9] D. Ivnitski, I. Abdel-Hamid, P. Atanasov and E. Wilkins, Review: Biosensors for detection of pathogenic bacteria, Biosensors and Bioelectronics 14 (1999), 599-624.

[10] M. Jackson, M.G. Sowa and H.H. Mantsch, Infrared spectroscopy: A new frontier in medicine, Biophysical Chemistry 68 (1997), 109-125.

[11] B. Lanyi, Classical and rapid identification methods for medically important bacteria, in: Methods in Microbiology, Vol. 19, R.R. Colwell and R. Grigorova, eds, Academic Press, London, 1987, pp. 1-67.

[12] K.-Z. Liu, L. Jia, S.M. Kelsey, A.C. Newland and H.H. Mantsch, Quantitative determination of apoptosis on leukemia cells by infrared spectroscopy, Apoptosis 6 (2001), 269-778.

[13] K. Maquelin, C. Kirschner, L.-P. Choo-Smith, N. Van Ben Braak, H. Endtz, D. Naumann and G.T. Puppels, Identification of medically relevant microorganisms by vibrational spectroscopy, Journal of Microbiological Methods 51 (2002), 255271.

[14] K.C. McCrae, H.H. Mantsch, J.A. Thliveris, J.E. Scott and R.A. Shaw, Analysis of neoplastic changes in mouse lung using Fourier-transform infrared spectroscopy, Vibrational Spectroscopy 28 (2001), 189-197.

[15] D. Naumann, D. Helm and H. Labischinski, Microbiological characterizations by FT-IR spectroscopy, Nature 351 (1991), $81-82$.

[16] M. O'Brien and R. Colwell, in: Methods in Microbiology, Vol. 19, R.R. Colwell and R. Grigorova, eds, Academic Press, London, 1987, pp. 69-104.

[17] C.P. Schultz, K.-L. Liu, P.D. Kerr and H.H. Mantsch, In situ infrared histopathology of keratinization in human oral/oropharyngeal squamous cell carcinoma, Oncology Research 10 (1998), 277-286.

[18] B.H. Stuart and D.J. Ando, Biological Applications of Infrared Spectroscopy, 1997.

[19] E. Taillandier and J. Liquier, Infrared spectroscopy of DNA, Methods Enzymol. 211 (1992), 307-335.

[20] Y. Wei Fang, C. Bai, Y. Tang, S.-B. Lin and L.-S. Kan, Hydrated water molecules of pyrimidine/purine/pyrimidine DNA triple helices as revealed by FTIR spectroscopy: a role of cytosine methylation, Journal of Biomolecular Structure and Dynamic 14 (1997), 485-493.

[21] M.R. Whitbeck, Second derivative infrared spectroscopy, Applied Spectroscopy 35 (1981), 93-95. 


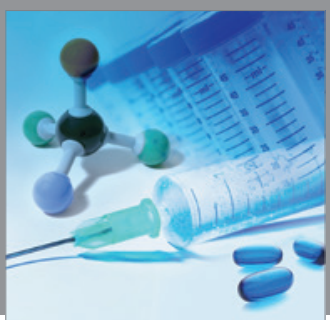

International Journal of

Medicinal Chemistry

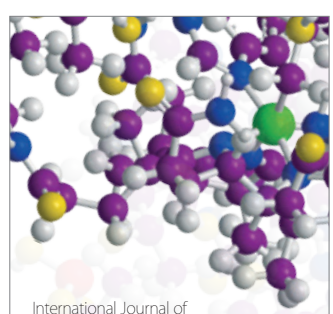

Carbohydrate Chemistry

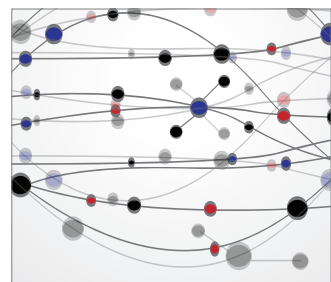

The Scientific World Journal
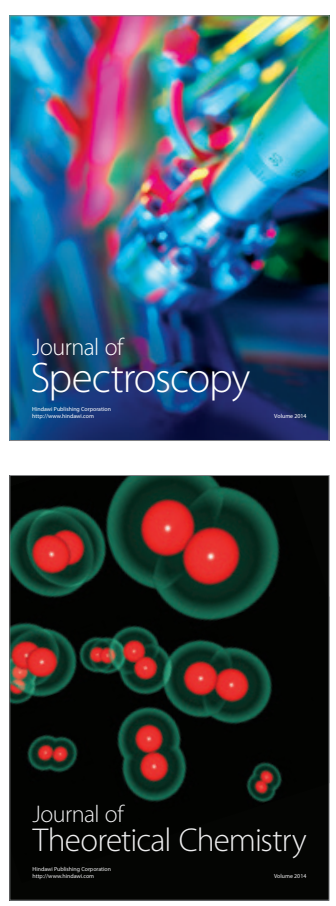
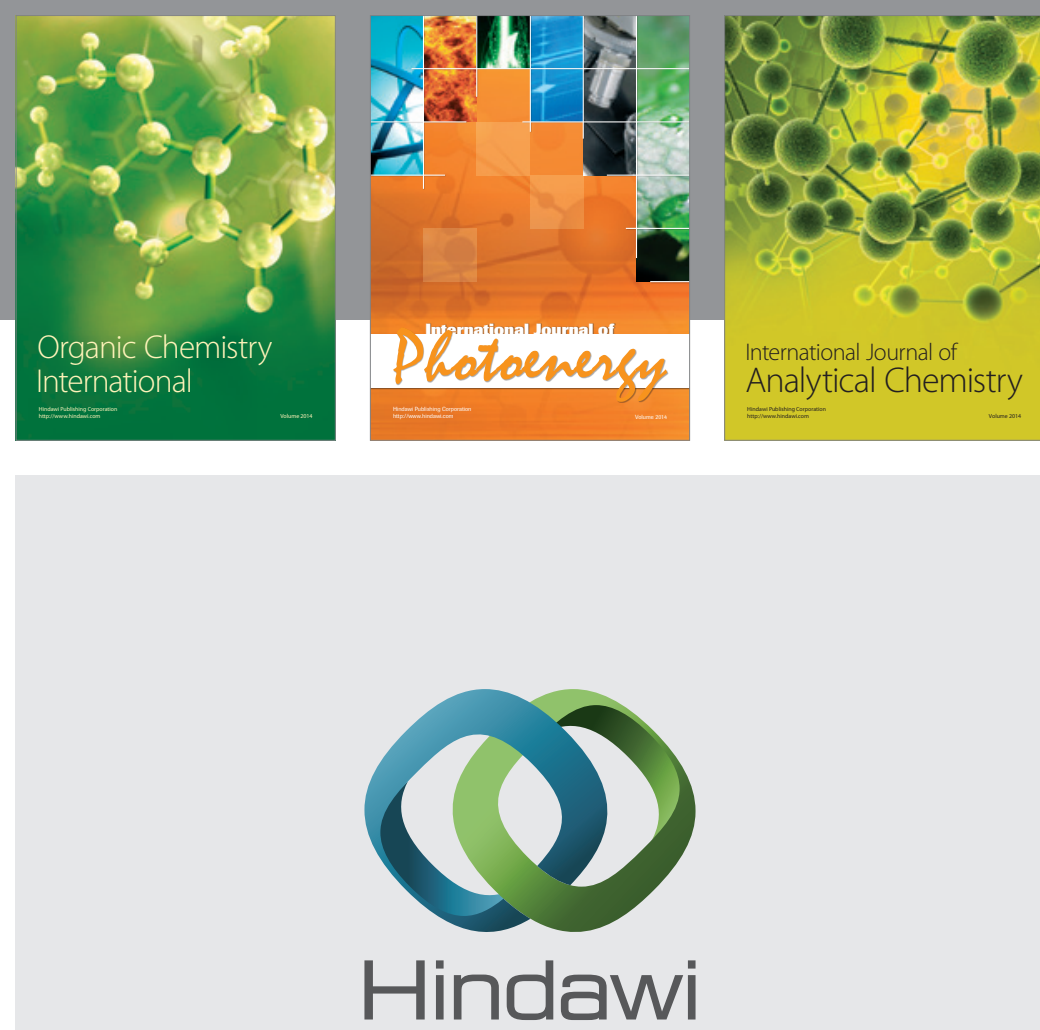

Submit your manuscripts at

http://www.hindawi.com
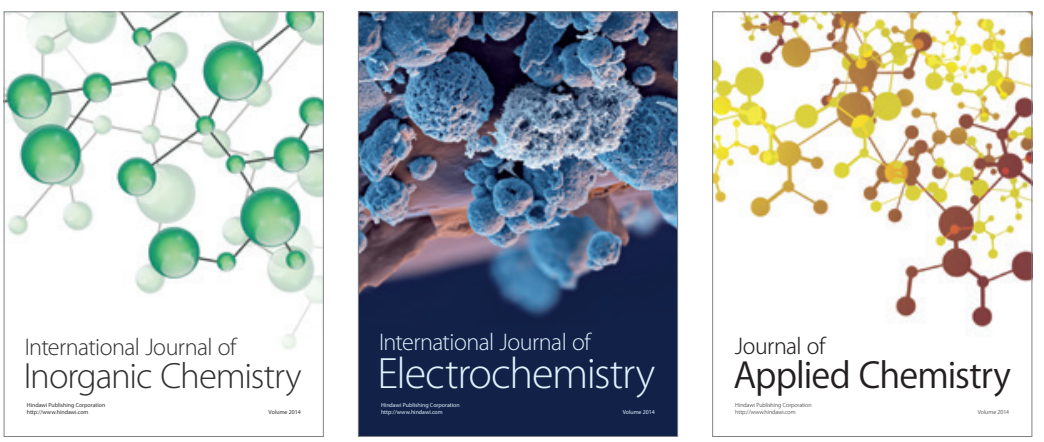

Journal of

Applied Chemistry
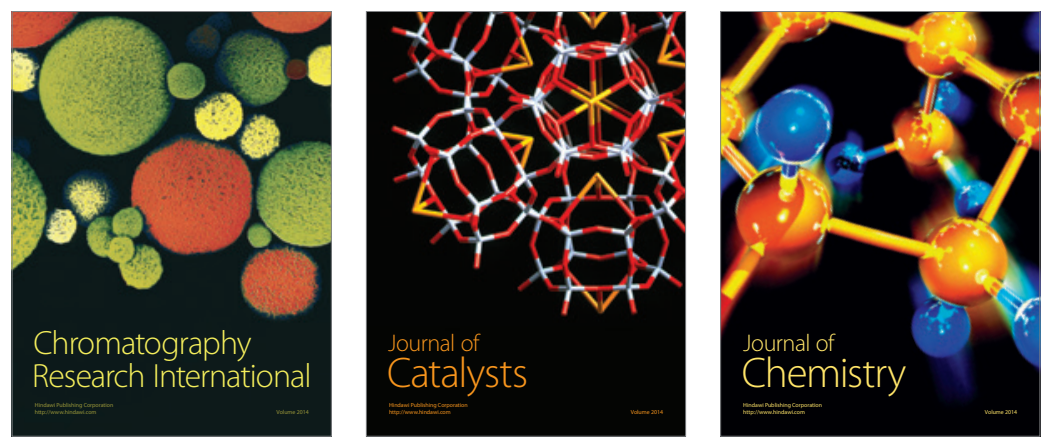
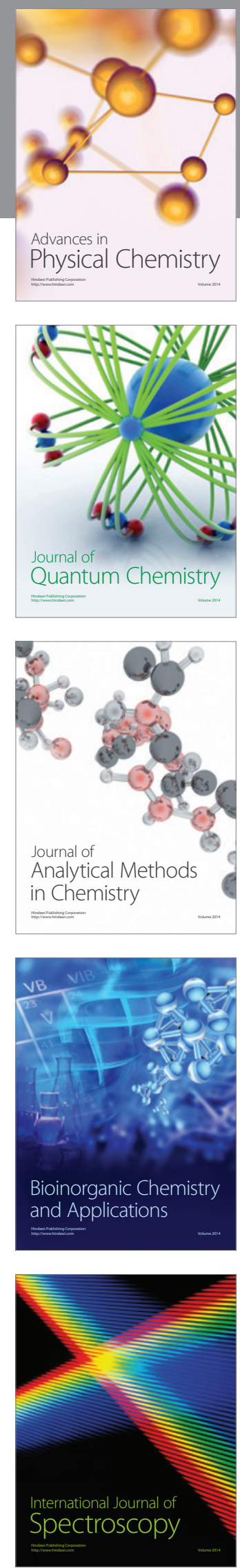